\title{
Use of Different Statistic Approaches on Variability in Hydrologic Variables ${ }^{\#}$
}

\author{
Kadri Yürekli ${ }^{1, a, *}$, Müberra Erdoğan ${ }^{1, b}$, Ömer Faruk Karaca ${ }^{2, c}$ \\ ${ }^{1}$ Department of Biosystem Engineering, Faculty of Agriculture, Gaziosmanpasa University, 60010 Tokat, Turkey \\ ${ }^{2}$ Department of Biosystems Engineering, Faculty of Engineering and Architecture, Bozok University, 66100 Yozgat, Turkey \\ *Corresponding author
}

\begin{tabular}{|c|c|}
\hline A R T I C LE I NFO & A B S T R A C T \\
\hline $\begin{array}{l}\text { "This study was presented as an oral } \\
\text { presentation at the 4th International } \\
\text { Anatolian Agriculture, Food, } \\
\text { Environment and Biology Congress } \\
\text { (Afyonkarahisar, TARGID 2019) } \\
\text { Research Article } \\
\text { Received : } 05 / 07 / 2019 \\
\text { Accepted : } 22 / 10 / 2019\end{array}$ & $\begin{array}{l}\text { The unnatural change in the globe under influence of devastating global warming has been quashing } \\
\text { the overall functioning of ecosystem since industrial revolution. Thus, the human-induced disaster } \\
\text { caused by proportional increase of greenhouse gases in the atmosphere has affected the normal } \\
\text { functioning of hydrologic cycle. Under the undesirable condition, the amount of hydrologic variables } \\
\text { began to diverge over time. Hydrologic variable should be homogeneous for the reliability of } \\
\text { hydraulic structure while predicting necessary design criteria for its construction. Therefore, the test } \\
\text { of whether this requirement is true should be performed in the context of any given hydrologic data's } \\
\text { homogeneity before being passed to the implementation of statistical approaches to the data. The } \\
\text { study carried out in Yesilirmak basin was realized on homogeneity of seasonal maximum streamflow } \\
\text { data from eight gauging stations operated by The General Directorate of State Hydraulic Works } \\
\text { (DSI). Yesilirmak River basin area is approximately } 5 \% \text { of surface area of Turkey. Yesilirmak River } \\
\text { is one of the major rivers of Turkey and its long is } 519 \text { kilometers. There are three main tributaries } \\
\text { of the Yesilirmak River, named as Kelkit, Cekerek and Tersakan. Its water is mostly used for } \\
\text { purposes as irrigation, drinking, fisheries and wildlife. The parametric and non-parametric } \\
\text { procedures, called as standard normal homogeneity, Pettitt, Buishand range and von Neuman ratio } \\
\text { were used for this reason. Statistically significant inhomogeneity with respect to the all of the statistic } \\
\text { tests taken into account in the study was detected in the considered streamflow data sequences } \\
\text { presented. }\end{array}$ \\
\hline
\end{tabular}

Türk Tarım - Gıda Bilim ve Teknoloji Dergisi 7(sp1): 1-5, 2019

\section{Hidrolojik Değişkenlerde Değişkenlik Üzerine Parametrik Olmayan Analizler}

\begin{tabular}{|c|c|}
\hline M A K A LE B İ L G İ S İ & Ö Z \\
\hline $\begin{array}{l}\text { Anahtar Kelimeler: } \\
\text { Akış } \\
\text { Homojenlik } \\
\text { Standart normal homojenlik testi } \\
\text { Bushand sıra testi } \\
\text { Von Neumann oran testi }\end{array}$ & $\begin{array}{l}\text { Yıkıcı küresel ısınmanın etkisi altındaki dünyada doğal olmayan değişim, sanayi devriminden bu } \\
\text { yana ekosistemin genel işlevini bozmaktadır. Bu nedenle, atmosferdeki sera gazlarının orantılı } \\
\text { şekilde artmasından kaynaklanan insan kaynaklı felaket hidrolojik döngünün normal çalışmasını } \\
\text { etkilemektedir. İstenmeyen koşullar altında, hidrolojik değişkenlerin miktarında zamanla sapmalar } \\
\text { meydana gelmektedir. Hidrolojik değişken, hidrolojik yapının yapımı için gerekli tasarım kriterlerini } \\
\text { tahmin ederken hidrolojik yapının güvenilirliği için homojen olması gerekmektedir. Bu nedenle, bu } \\
\text { gerekliliğin doğru olup olmadığının testi, verilere istatistiksel yaklaşımların uygulanmasına } \\
\text { geçilmeden önce verilen hidrolojik verilerin homojenlik durumuna bakılmalıdır. Yeşilırmak } \\
\text { havzasında yapılan bu çalışma, Devlet Su İ̧leri Genel Müdürlüğü (DSİ) tarafından işletilen sekiz } \\
\text { ölçüm istasyonundan elde edilen mevsimsel maksimum akış verilerinin homojenliği üzerinde } \\
\text { gerçekleştirilmiştir. Yeşilırmak Nehri havzası alanı, Türkiye yüzey alanının yaklaşı } \\
\text { \%5'idir.Yeşilırmak Nehri, Türkiye'nin en büyük nehirlerinden biri olup, uzunluğu } 519 \text { kilometredir. } \\
\text { Yeşilırmak Nehri'nin Kelkit, Çekerek ve Tersakan olarak adlandırılan üç ana kolu vardır. Yeşilırmak } \\
\text { suyu çoğunlukla sulama, içme, balıkçılık ve yaban hayatı gibi amaçlar için kullanılmaktadır. Bu } \\
\text { sebeple standart normal homojenlik testi, pettit testi, buishand sıra testi ve von Neumann oranı olarak } \\
\text { adlandırılan parametrik ve parametrik olmayan yöntemler kullanılmıştır. Çalışmada dikkate alınan } \\
\text { tüm istatistiksel testlere göre verilen akış verilerinin istatistiksel olarak anlamlı homojen olmadığ1 } \\
\text { sonucuna ulaşılmışıtır. }\end{array}$ \\
\hline
\end{tabular}




\section{Introduction}

Due to effect of global warming on hydrologic cycle, especially over last century, this human-induced disaster has begun to change the shape of frequency distribution dealing with hydro-meteorological variables. This has led to the deterioration of the desired homogeneity for hydrologic variables. Based on variation in temperature and precipitation patterns, its impact was quite self-evident by drought and floods events in many parts of the globe. Giorgi (2006) stated that Mediterranean region was enormously sensitive while being reported an increasing on heavy precipitation events in the last half of the 20th century in IPCC (2013). The assumption of stationarity in hydrologic variables is a need for construction of a reliable hydraulic structure. The predicted design value for the water-related structure is obtained based on statistical behavior of the hydrologic variable. The non-stationarity in the variables will influence planning, management and cost of the structure. In this sense, the data analysis should be fulfilled for solidity of hydraulic structure. Inhomogeneous data sequences should be homogenized to estimate design values with no doubt for any hydraulic structure.

Homogeneity analysis of hydro-climatic data can be performed by both parametric and non-parametric statistical methods. The most prominent feature of nonparametric methods according to that of parametric is that there is no pre assumption to comply with any probability distribution of data. Sen (2018) tested homogeneity of streamflow data sets predicted for rivers in Yesilirmak basin with Mann-Whitney U method. Yurekli (2015) applied the Mann-Whitney $U$ test to judge on whether seasonal rainfall series from 19 rainfall stations over the upper Euphrates and Tigris rivers basin were homogeneous. Homogeneity condition was performed by using the double-mass curve technique for inhomogeneous data sets. Horwath et al. (2016) used standard normal homogeneity (SNHT), Pettitt(PT), Buishand range(BRT) and von Neuman ratio(VNRT) tests to detect change point in monthly, seasonal and annual discharge series. Kang and
Yusof (2012) analyzed homogeneity of daily rainfall series by the same approaches considered in Horwath et al. (2016). Demircan (2018) carried out analysis on homogeneity concerning with streamflow series by Kruskal Wallis and Levene test. Yerdelen (2013) used run approach in testing whether mean annual discharge series came from the same distribution as well as applying PT and SNHT test to bring out change points in the data. The basic objective of the study is to apply the methods (SNHT, PT, BRT and VNRT) detecting change points in discharge data sequences from Yesilirmak basin.

\section{Material and Methods}

Yesilirmak River basin area which was selected as study region, is approximately 5\% of surface area of Turkey. The river basin is situated between $39^{\circ} 30^{\prime}$ ve $41^{\circ}$ $21^{\prime}$ North latitude and $34^{\circ} 40$ 've $39^{\circ} 48^{\prime}$ 'East longitude. Yesilirmak River is one of the major rivers of Turkey and its long is 519 kilometres. The river arises from Kosedag located in the northeast of Sivas province and, joins to Black Sea in district of Carsamba of Samsun province. There are three main tributaries of the Yesilirmak River, named as Kelkit, Cekerek and Tersakan. Its water is mostly used for purposes as irrigation, drinking, fisheries and wildlife. But, the river has been exposed to pollution due to population growth and rapid industrialization. In terms of land use, presence of forest, cultivated land and pasture land in the basin are about 39\%, 39\% and 19\%, respectively. Due to irregular streamflow regime of Yesilirmak river, flooding in river basin occurs in various times, especially during the period in April, May and June months (Munsuz and Ünver 1983; Yürekli, 2017; Kurunç et al., 2005; Lekesiz et al., 2007).

In the study, data from eight streamflow gauging stations operated by The General Directorate of State Hydraulic Works (DSI) was used as a material. Some characteristics belonging to eight stations were given in Table 1. Its geographical locations is in Figure 1.
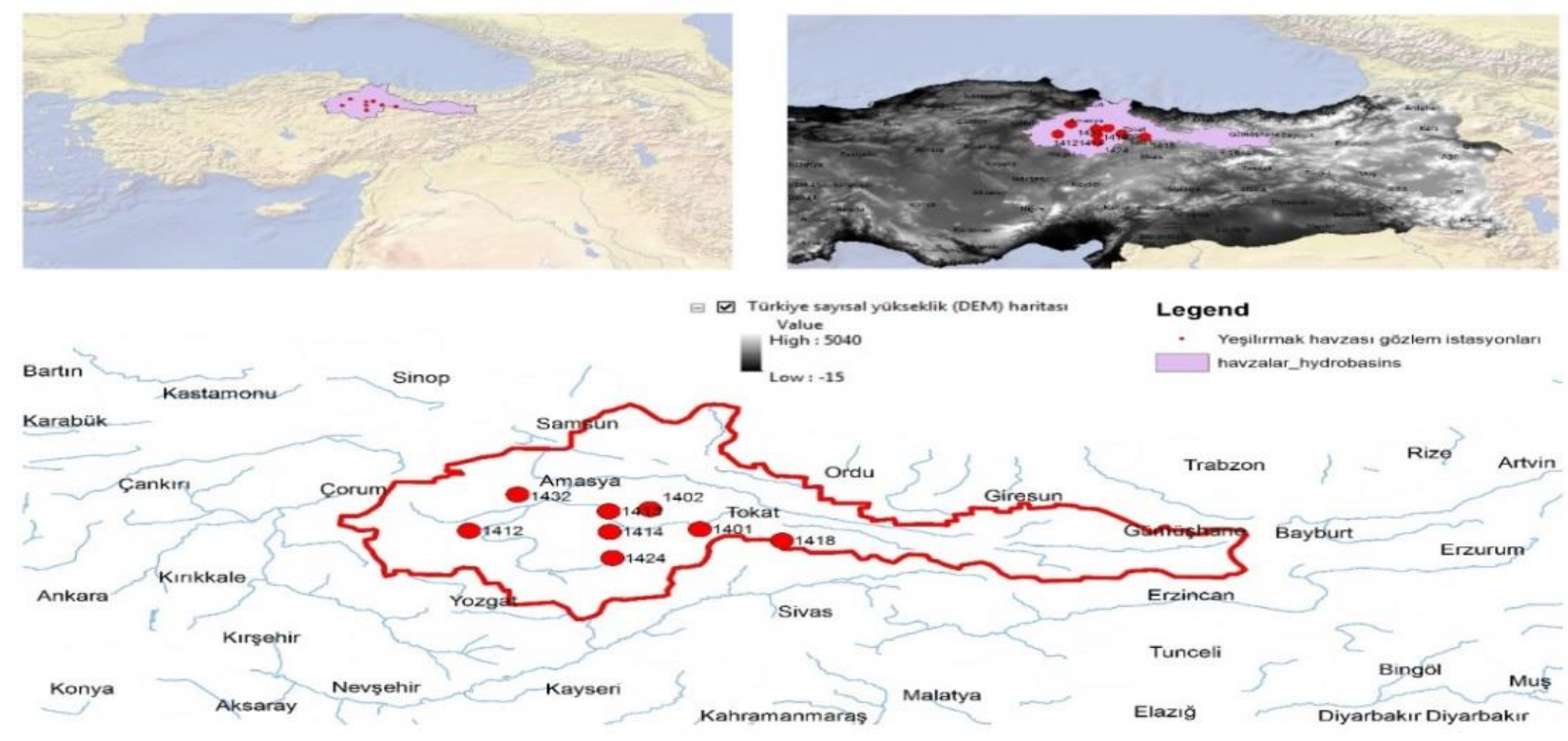

Figure 1 The Geographical Location and Stations of Yesilirmak Basin in Turkey 
Table 1 The streamflow stations used in the study

\begin{tabular}{l|lccc}
\hline $\begin{array}{c}\text { Station } \\
\text { Code }\end{array}$ & \multicolumn{1}{|c}{$\begin{array}{c}\text { Streamflow } \\
\text { (Location) }\end{array}$} & $\begin{array}{c}\text { Longitude } \\
\text { (East) }\end{array}$ & $\begin{array}{c}\text { Latitude } \\
\text { (North) }\end{array}$ & $\begin{array}{c}\text { Record } \\
\text { Length }\end{array}$ \\
\hline 1401 & Kelkit Stream (Fatli) & $36^{\circ} 59^{\prime} 56^{\prime \prime}$ & $40^{\circ} 28^{\prime} 42^{\prime \prime}$ & 74 \\
1402 & Yesilirmak (Kale) & $36^{\circ} 30^{\prime} 45^{\prime \prime}$ & $40^{\circ} 46^{\prime} 18^{\prime \prime}$ & 75 \\
1412 & Çorum Çat River (Seyhoglu Bridge) & $35^{\circ} 25^{\prime} 03^{\prime \prime}$ & $40^{\circ} 27^{\prime} 06^{\prime \prime}$ & 60 \\
1413 & Yesilirmak (Durucasu) & $36^{\circ} 06^{\prime} 43^{\prime \prime}$ & $40^{\circ} 44^{\prime} 40^{\prime \prime}$ & 58 \\
1414 & Yesilirmak (Sütlüce) & $36^{\circ} 07^{\prime} 05^{\prime \prime}$ & $40^{\circ} 26^{\prime} 03^{\prime \prime}$ & 59 \\
1418 & Yesilirmak (Gömelönü) & $37^{\circ} 07^{\prime} 43^{\prime \prime}$ & $40^{\circ} 18^{\prime} 42^{\prime \prime}$ & 51 \\
1424 & Çekerek Stream (Cirdak Bridge) & $36^{\circ} 08^{\prime} 47^{\prime \prime}$ & $40^{\circ} 0^{\prime} 29^{\prime \prime}$ & 45 \\
1432 & Tersakan Stream (Ahmetsaray) & $35^{\circ} 53^{\prime} 15^{\prime \prime}$ & $40^{\circ} 59^{\prime} 13^{\prime \prime}$ & 14 \\
\hline
\end{tabular}

Table 2 Homogeneity test results of the station 1401

\begin{tabular}{l|cccccccc}
\multirow{2}{*}{ Season } & \multicolumn{3}{c}{$\mathrm{PT}$} & \multicolumn{2}{c}{ SNHT } & \multicolumn{2}{c}{ BRT } & \multicolumn{2}{c}{ VNRT } \\
\cline { 2 - 9 } & $\mathrm{K}$ & $\mathrm{P}$ & $\mathrm{T}_{\mathrm{o}}$ & $\mathrm{P}$ & $\mathrm{Q}$ & $\mathrm{P}$ & $\mathrm{N}$ & $\mathrm{P}$ \\
\hline S-I & 1332 & 0.000 & 52.29 & 0.000 & 30.88 & 0.000 & 0.056 & 0.000 \\
S-II & 1332 & 0.000 & 58.81 & 0.000 & 31.05 & 0.000 & 0.009 & 0.000 \\
S-III & 1332 & 0.000 & 47.02 & 0.000 & 29.47 & 0.000 & 0.016 & 0.000 \\
S-IV & 1332 & 0.000 & 60.81 & 0.000 & 32.44 & 0.000 & 0.005 & 0.000 \\
\hline
\end{tabular}

Table 3 Homogeneity test results of the station 1402

\begin{tabular}{l|cccccccc}
\hline \multirow{2}{*}{ Season } & \multicolumn{3}{|c}{ PT } & \multicolumn{4}{c}{ SNHT } & \multicolumn{2}{c}{ BRT } & \multicolumn{2}{c}{ VNRT } \\
\cline { 2 - 9 } & $\mathrm{K}$ & $\mathrm{P}$ & $\mathrm{T}_{\mathrm{o}}$ & $\mathrm{P}$ & $\mathrm{Q}$ & $\mathrm{P}$ & $\mathrm{N}$ & $\mathrm{P}$ \\
\hline S-I & 1369 & 0.000 & 51.18 & 0.000 & 29.60 & 0.000 & 0.057 & 0.000 \\
S-II & 1369 & 0.000 & 44.21 & 0.000 & 27.48 & 0.000 & 0.019 & 0.000 \\
S-III & 1369 & 0.000 & 40.72 & 0.000 & 24.82 & 0.000 & 0.081 & 0.000 \\
S-IV & 1369 & 0.000 & 43.65 & 0.000 & 25.94 & 0.000 & 0.068 & 0.000 \\
\hline
\end{tabular}

Table 4 Homogeneity test results of the station 1412

\begin{tabular}{l|cccccccc}
\hline \multirow{2}{*}{ Season } & \multicolumn{3}{c}{$\mathrm{PT}$} & \multicolumn{2}{c}{ SNHT } & \multicolumn{2}{c}{ BRT } & \multicolumn{2}{c}{ VNRT } \\
\cline { 2 - 9 } & $\mathrm{K}$ & $\mathrm{P}$ & $\mathrm{T}_{\mathrm{o}}$ & $\mathrm{P}$ & $\mathrm{Q}$ & $\mathrm{P}$ & $\mathrm{N}$ & $\mathrm{P}$ \\
\hline S-I & 870 & 0.000 & 47.44 & 0.000 & 12.32 & 0.000 & 0.301 & 0.000 \\
S-II & 870 & 0.000 & 33.51 & 0.000 & 19.94 & 0.000 & 0.212 & 0.000 \\
S-III & 870 & 0.000 & 42.89 & 0.000 & 23.11 & 0.000 & 0.012 & 0.000 \\
S-IV & 870 & 0.000 & 47.38 & 0.000 & 14.70 & 0.000 & 0.131 & 0.000 \\
\hline
\end{tabular}

In the study, streamflows of the period in which there is the missing data were completed by using Grey System Theory (Wen, 2004). Monthly maximum streamflow value for each month of the relevant year was selected among the daily mean streamflows for the study. But, the study was conducted on the data sequences in four seasons, names of which were season-I (S-I), season-II (S-II), season-III (SIII) and season-IV (S-IV), respectively. The maximum data of each season was formed by selecting among monthly maximum streamflow values in October, November and December for S-I, January, February and March for S-II, April, May and June for S-III and, July, August and September for S-IV.

The homogeneity analysis of seasonal maximum data set from eight streamflow gauging stations was performed with the approaches, including Pettitt(PT), standard normal homogeneity (SNHT), Buishand range(BRT) and von Neuman ratio(VNRT) tests. A detailed description of these methods was not intended for the purposes of reducing volume in the article. These approaches are disclosed in the literature in detail (Amjadi, 2015).

\section{Results and discussions}

The four homogeneity tests abbreviated as PT, SNHT, BRT and VNRT by considering 5\% significance level was applied to the seasonal maximum steramflow series from Yesilirmak River and its tributaries. The null hypothesis $\left(\mathrm{H}_{\mathrm{o}}\right)$ of these homogeneity tests deems that the data sets are homogeneous while alternative hypothesis $\left(\mathrm{H}_{1}\right)$ assumes that there is a change in the data. The null hypothesis $\left(\mathrm{H}_{\mathrm{o}}\right)$ is rejected when the calculated $\mathrm{P}$-value belonging to any homogeneity approach is lower than the critical value $(5 \%)$, then the alternative hypothesis $\left(\mathrm{H}_{1}\right)$ is accepted. The results of these four tests are presented in the following tables. The test statistic measures $\left(\mathrm{K}, \mathrm{T}_{\mathrm{o}}, \mathrm{Q}\right.$ and $\mathrm{N}$ ) for every homogeneity procedure and their corresponding probability values $(\mathrm{P})$ are given in the tables (Table 2, 3, 4, 5, 6, 7, 8, 9). As can be seen in all tables, the aforementioned homogeneity tests detected inhomogeneity or the existence of a change in streamflow data sets of four seasons for each station considered in the study. 
According to categorization in Schonviese and Rapp (1997) whose classification related to precipitation is doubtful, suspect and useful if the rejection of the null hypothesis is realized in the two, three or four and one or none of the homogeneity procedures given in the study, respectively. The results of the study imply that all data sequences are suspect with respect to the above classification. But, these four tests in some researches presented the inconsistent results (Feng et al., 2004; Sahin and Cigizoglu, 2010; Omar et al., 2017). In this context, Omar et al. (2017) and Talaee et al. (2014) drawn attention the relationship between data homogeneity and reliably detecting trend.

Table 5 Homogeneity test results of the station 1413

\begin{tabular}{l|cccccccc}
\hline \multirow{2}{*}{ Season } & \multicolumn{3}{|c}{$\mathrm{PT}$} & \multicolumn{2}{c}{ SNHT } & \multicolumn{2}{c}{ BRT } & \multicolumn{2}{c}{ VNRT } \\
\cline { 2 - 9 } & $\mathrm{K}$ & $\mathrm{P}$ & $\mathrm{T}_{\mathrm{o}}$ & $\mathrm{P}$ & $\mathrm{Q}$ & $\mathrm{P}$ & $\mathrm{N}$ & $\mathrm{P}$ \\
\hline S-I & 812 & 0.000 & 37.88 & 0.000 & 18.31 & 0.000 & 0.114 & 0.000 \\
S-II & 812 & 0.000 & 37.37 & 0.000 & 23.01 & 0.000 & 0.065 & 0.000 \\
S-III & 812 & 0.000 & 37.88 & 0.000 & 22.32 & 0.000 & 0.044 & 0.000 \\
S-IV & 812 & 0.000 & 45.30 & 0.000 & 14.43 & 0.000 & 0.562 & 0.000 \\
\hline
\end{tabular}

Table 6 Homogeneity test results of the station 1414

\begin{tabular}{l|cccccccc}
\hline \multirow{2}{*}{ Season } & \multicolumn{3}{c}{$\mathrm{PT}$} & \multicolumn{2}{c}{ SNHT } & \multicolumn{2}{c}{ BRT } & \multicolumn{2}{c}{ VNRT } \\
\cline { 2 - 9 } & $\mathrm{K}$ & $\mathrm{P}$ & $\mathrm{T}_{\mathrm{o}}$ & $\mathrm{P}$ & $\mathrm{Q}$ & $\mathrm{P}$ & $\mathrm{N}$ & $\mathrm{P}$ \\
\hline S-I & 841 & 0.000 & 43.48 & 0.000 & 24.64 & 0.000 & 0.011 & 0.000 \\
S-II & 841 & 0.000 & 38.57 & 0.000 & 23.60 & 0.000 & 0.026 & 0.000 \\
S-III & 841 & 0.000 & 38.94 & 0.000 & 23.78 & 0.000 & 0.014 & 0.000 \\
S-IV & 841 & 0.000 & 33.95 & 0.000 & 21.12 & 0.000 & 0.080 & 0.000 \\
\hline
\end{tabular}

Table 7 Homogeneity test results of the station 1418

\begin{tabular}{l|cccccccc}
\hline \multirow{2}{*}{ Season } & \multicolumn{3}{c}{$\mathrm{PT}$} & \multicolumn{2}{c}{ SNHT } & \multicolumn{2}{c}{ BRT } & \multicolumn{2}{c}{ VNRT } \\
\cline { 2 - 9 } & $\mathrm{K}$ & $\mathrm{P}$ & $\mathrm{T}_{\mathrm{o}}$ & $\mathrm{P}$ & $\mathrm{Q}$ & $\mathrm{P}$ & $\mathrm{N}$ & $\mathrm{P}$ \\
\hline S-I & 625 & 0.000 & 38.18 & 0.000 & 17.82 & 0.000 & 0.042 & 0.000 \\
S-II & 625 & 0.000 & 25.25 & 0.000 & 17.24 & 0.000 & 0.224 & 0.000 \\
S-III & 624 & 0.000 & 35.12 & 0.000 & 21.03 & 0.000 & 0.012 & 0.000 \\
S-IV & 625 & 0.000 & 36.37 & 0.000 & 16.76 & 0.000 & 0.047 & 0.000 \\
\hline
\end{tabular}

Table 8 Homogeneity test results of the station 1424

\begin{tabular}{l|cccccccc}
\hline \multirow{2}{*}{ Season } & \multicolumn{3}{c}{$\mathrm{PT}$} & \multicolumn{2}{c}{ SNHT } & \multicolumn{2}{c}{ BRT } & \multicolumn{2}{c}{ VNRT } \\
\cline { 2 - 9 } & $\mathrm{K}$ & $\mathrm{P}$ & $\mathrm{T}_{\mathrm{o}}$ & $\mathrm{P}$ & $\mathrm{Q}$ & $\mathrm{P}$ & $\mathrm{N}$ & $\mathrm{P}$ \\
\hline S-I & 484 & 0.000 & 42.02 & 0.000 & 7.47 & 0.000 & 0.832 & 0.000 \\
S-II & 484 & 0.000 & 30.28 & 0.000 & 18.29 & 0.000 & 0.026 & 0.000 \\
S-III & 484 & 0.000 & 28.25 & 0.000 & 17.37 & 0.000 & 0.061 & 0.000 \\
S-IV & 484 & 0.000 & 34.91 & 0.000 & 15.98 & 0.000 & 0.035 & 0.000 \\
\hline
\end{tabular}

Table 9 Homogeneity test results of the station 1432

\begin{tabular}{l|cccccccc}
\hline \multirow{2}{*}{ Season } & \multicolumn{3}{c}{$\mathrm{PT}$} & \multicolumn{2}{c}{ SNHT } & \multicolumn{2}{c}{ BRT } & \multicolumn{2}{c}{ VNRT } \\
\cline { 2 - 9 } & $\mathrm{K}$ & $\mathrm{P}$ & $\mathrm{T}_{\mathrm{o}}$ & $\mathrm{P}$ & $\mathrm{Q}$ & $\mathrm{P}$ & $\mathrm{N}$ & $\mathrm{P}$ \\
\hline S-I & 42 & 0.000 & 10.30 & 0.000 & 5.51 & 0.000 & 0.138 & 0.000 \\
S-II & 42 & 0.000 & 8.67 & 0.001 & 5.37 & 0.001 & 0.177 & 0.000 \\
S-III & 42 & 0.000 & 11.03 & 0.001 & 5.75 & 0.001 & 0.156 & 0.000 \\
S-IV & 42 & 0.000 & 11.24 & 0.004 & 4.55 & 0.000 & 0.324 & 0.000 \\
\hline
\end{tabular}

\section{Conclusion}

The study was conducted to check whether the seasonal data sequences from streamflow gauging stations on Yesilirmak river and its tributaries were homogeneous or not. In this sense, the four homogeneity procedures, named Pettitt(PT), standard normal homogeneity (SNHT), Buishand range(BRT) and von Neuman ratio(VNRT) were used for the mentioned goal. All of the data sets showed an inhomogeneous character. This implies a threat of a setback in accomplishing the expected benefit from any water-related structure. Reliably predicting design value required for the construction of any hydraulic structure is very important for building safety. This can only be achieve with reliable data. A homogeneous hydrologic data is crucial to reach to the reliable design value.

\section{References}

Amjadi M. 2015. Statistic and Probabilistic Variations and Rainfall Predictions of TRNC. Eastern Mediterranean University, Gazimagusa North Cyprus, Master of Science in Civil Engineering, $175 \mathrm{p}$.

Demircan Y. 2018. Analysis of Variability in Streamflows of Cekerek Stream. Gaziosmanpasa University, Graduate School of Natural and Applied Sciences Department of Biosystems Engineering, Master Thesis, 68p. (In Turkish)

Giorgi F. 2006. Climate change Hot-Spots. Geophysical. Research Letters, 33: L08707.

Feng S, Hu Q, Qian W. 2004. Quality control of daily meteorological data in China, 1951-2000: A new dataset. Int J Climatol 24:853-870.

Horwath CS, Batınas RH, Rosian GH, Kinga-Olga R. 2016. Variability and Trends in the Viseu River Runoff Regime. Studia Ubb Geographia, 2, 63-72. 
Kang HM, Yusof F. 2012. Homogeneity Tests on Daily Rainfall Series in Peninsular Malaysia. International Journal of Contemporary Mathematical Sciences, 7(1), 9-22.

Kurunc A, Yurekli K, Cevik O. 2005. Performance of Two Stochastic Approaches for Simulating river Water Quality and Streamflow. Environmental Modeling \& Software, 20: 1995-2000.

Lekesiz MC, Mesci Y, Yorulmaz T. 2007. River Basin Management Applications Yesilirmak River Basin Development Project Model. International Congress River Basin Management, 22-24 March, Antalya.

Munsuz N, Ünver İ. 1983. Türkiye Suları, Ank. Üniv. Ziraat Fak. Yay. 392 s. (In Turkish)

Omar MA, Agha M, Bahcacı SC, Sarlak N. 2017. Homogeneity Analysis of Precipitation Series in North Iraq. IOSR Journal of Applied Geology and Geophysics, 5(3), 57-63.

Schonwiese CD, Rapp J. 1997. Climate Trend Atlas of Europe Based on Observations 1891-1990. Kluwer Academic Publishers: Dordrecht, The Netherlands.

Sahin S, Cigizoglu HK. 2010. Homogeneity analysis of Turkish meteorological data set. Hydrol. Process, 24(8): 981-992.
Sen S. 2018. Streamflows of Yesilirmak River with Grey Systems Approach. Gaziosmanpasa University, Graduate School of Natural and Applied Sciences Department of Biosystems Engineering, Master Thesis, 68p. (In Turkish)

Talaee PH, Kouchakzadeh M, Some'e BS. 2014. Homogeneity analysis of precipitation series in Iran. Theoretical and Applied Climatology, 118(1-2): 297- 305.

Wen KL. 2004. Grey Systems: Modeling and Prediction. Yang's Scientific Research Institute, $253 \mathrm{p}$.

Yerdelen C. 2013. Investigation of Trend Analysis and Change Point Detection for Annual Mean Streamflows of Susurluk Basin. Dokuz Eylul University, Engineering Faculty, Journal of Science and Engineering, 15(2), 77-87. (In Turkish)

Yurekli K. 2015. Impact of climate variability on precipitation in the Upper Euphrates-Tigris Rivers Basin of Southeast Turkey. Atmospheric Research, 154, 25-38.

Yurekli K. 2017. Variability Analysis on Water Quality of Streamflow from Yesilirmak Basin in Turkey. Gaziosmanpaşa Üniversitesi Ziraat Fakültesi Dergisi, 34 (1), 33-37. 